\title{
METODE EXTENDING CONCEPTS THROUGHT LANGUAGE ACTIVITIES (ECOLA) DALAM PEMBELAJARAN MEMBACA PAMAHAMAN BIOGRAFI
}

\author{
Heri Susanto \\ MGMP Bahasa Sunda Kota Bandung \\ Pos-el: rie_susanto32@yahoo.com
}

\begin{abstract}
Abstrak
Penelitian ini dilatarbelakangi oleh kurangnya kemampuan siswa dalam membaca pemahaman biografi pada siswa kelas XI IPA 2 SMA Laboratorium Percontohan UPI tahun pelajaran 2013/2014. Tujuan dari Penelitian ini untuk mendeskripsikankemampuan membaca pemahaman biografi pada siswa sebelum dan sesudah menggunakan metode ECOLA, meningkat atau tidaknya kemampuan membaca pemahaman siswa, dan mengetahui perbedaan yang signifikan antara sebelum dan sesudah menggunakan metode ECOLA dalam pemahaman membaca biografi. Métode penelitian yang digunakan yaitu metode kuasi eksperimen, dengan tekhnik tés dalam bentuk pilihan ganda. Dari penelitian ini ditemukan, kemampuan siswa sebelum menggunakan metode ECOLAyaitu belum mampu denganrata-rata pemahaman 63,59. Berdasarkan aspeknya, ditemukan bahwa aspék literal 13, interprétasi 5, dan elaborasi 1,4. Sesudah menggunakan metode ECOLA siswa menjadi mampu dengan rata-rata pemahaman 78,59. Berdasarkan aspeknya, aspék literal 17, interprétasi 5,2, dan elaborasi 1,9. Metode ECOLA bisa meningkatkan kemampuan pemahaman siswa, dari rata-rata 63,59 menjadi 78,59. Selain itu, ada beda yang signifikan yaitu, thitung $=11,03>$ ttabel 2,48, sehingga metode ECOLA cocok digunakeun dalam meningkatkan kemampuan membaca pemahaman biografi siswa kelas XI SMA Laboratorium Percontohan UPI taun ajaran 2013/2014, dan bisa dipakai oleh guru dalam pembelajaran membaca pemahaman biografi.
\end{abstract}

Kata kunci: ECOLA, Membaca pemahaman, dan biografi.

\section{EXTENDING CONCEPTS THROUGHT LANGUAGE ACTIVITIES (ECOLA) METOD OF BIOGRAPHY COMPREHENSION READING}

\begin{abstract}
This research is based on students' disability of biography comprehension reading of the XI IPA 2 UPI Laboratorium Highschool 2013/2014 school period. This research aimed to describe the students' capability, whether it's increased or not, and for knowing the significant differences of the students' capability of biography comprehension reading before and after applied ECOLA method. The method of this research is experimental quotion, with the multiple-choice test technique. This research found, the students' haven't been able to to read biography comprehension before use ECOLA method, with the average comprehension is 63,59. Based on the literal aspect 13, interpretation 5, and elaboration 1,4. After using the ECOLA method the students were capable with the average comprehension 78,59. Based on the aspect, literal aspect 17, interpretation 5,2, and elaboration 1,9. ECOLA method could increase the students' comprehension capability, from the average 63,59 become 78,59. Moreover, there's a significant difference, $t_{\text {sum }}=11,03>t_{\text {table }}=2,48$, with the result that ECOLA method is suitable to be used in improving the students of class XI of the UPI Laboratorium Highschool's capability of biography comprehension reading.
\end{abstract}


Keyword: ECOLA, reading comprehensionand biography.

\section{PENDAHULUAN}

Bahasa merupakan aspek yang penting dalam kehidupan manusia, sebagai alat komunikasi dalam bermasyarakat. Dengan adanya bahasa, terjadi proses bertukar fikiran secara langsung. Bahasa juga sebagai alat untuk mewariskan budaya secara turun temurun.

Kemampuan berbahasa terdiri dari empat aspek, yaitu mendengarkan, berbicara, membaca, dan menulis. Salah satu kemampuan bahasa sunda di SMA yang memiliki peran penting adalah membaca.

Somadayo (2011, hlm. 1) mengatakan bahwa membaca merupakan salah satu aspek keterampilan berbahasa yang sangat penting disamping tiga keterampilan bahasa yang lainnya. Hal itu disebabkan karena membaca merupakan sarana untuk mengenal dunia lain yang ingin diketahui sehingga manusia bisa memperluas dan menggali pasan-pesan tertulis yang ada dalam bahan bacaan.

Menurut Broughton (dalam Tarigan, 2008, hlm. 12) ada dua aspek penting di dalam membaca, yaitu keterampilan yang bersifat mekanis, dan keterampilan yang bersifat pemahaman.

Keterampilan mekanis berada pada tahapan yang paling bawah (lower order). Aspeknya, yaitu: mengenal struktur huruf, mengenal unsur-unsur linguistik (fonem/grafem, kata, frase, pola klausa, kalimat, dll), mengenal hubungan pola ejahan dan suara (kemampuan bersuara dalam bentuk tulisan atau "to bark print", serta cepatnya membaca ada pada tahapan yang lambat.

Kemampuan pemahaman berada pada tahapan yang lebih tinggi (high order). Aspeknya, yaitu:memahami arti secara sederhana (leksikal, gramatikal, retorikal), memahami makna (maksud dan tujuan pengarang, relevansi/keadaan kebudayaan, dan réaksi pembaca), évaluasi atau memberi nilai (isi, bentuk), serta cepatnya membaca disesuaikan dengan keadaan (fleksibel).

Tarigan (dalam Somadayo, 2011, hlm. 8) menyebutkan bahwa membaca pemahaman merupakan jenis membaca yang memiliki tujuan untuk memahami standar-standar atau norma-norma kesastraan (literal standars), resensi kritis (critical reviw), drama tulis (printed drama), dan pola-pola fiksi (pattrens of ficion).

Anderson (1981, hlm.106) dalamUsep Kuswari (1995, hlm.11) dalam skripsi Evita Awalia (2013, hlm. 22) kemampuan membaca pemahaman bisa diukur melalui tiga tingkatan, yaitu: (1) tingkat literal, (2) tingkat interpretasi, dan (3) tingkat pamahaman di luar wacana. Tingkat literal menanyakan halhal yang ditemukan didalam bacaan, tingkat interprétasi menanyakan hal-hal yang dimaksud oleh pengarang, dan tingkat pemahaman yang ketiga menanyakan hal-hal yang ada diluar wacana.

Menurut Ernest (2008) dalam skripsi Mega Rahayu (2011, hlm.27), biografi mengandung arti sebagai riwayat hidup yang terbilang lengkap, tentang kehidupan seseorang yang menceritakan tentang pengalaman, kegiatan, sifat, tempramennya, dan tentang lingkungan yang ditulis oleh orang lain.

Berdasarkan observasi di lapangan, pelajaran membaca biografi di sekolah sering dianggap sebagai pelajaran yang mudah oleh siswa. Sedangkan pada kenyataannya siswa masih belum bisa membaca dan memahami bahan bacaan dengan baik. Hal ini disebabkan karena siswa tidak memiliki tujuan untuk dapat memahami apa yang dibacanya. Salah satu tujuan membaca biografi. Berdasarkan silabus adalah supaya siswa bisa memahami isi biografi.

Berdasarkan observasi yang telah dilakukan, siswakelas XI IPA 2SMA 
Laboratorium Percontohan UPI Bandung tahun ajaran 2013/2014 masih belum mampu dalam membaca pemahaman biografi. Terdapat beberapa faktor yang mempengaruhi hal tersebut, diantaranya yaitu siswa tidak memiliki keinginan untuk memahami biografi tersebut, kurangnya keinginan untuk bertanya mengenai hal yang tidak dimengerti, dan bahan bacaan biografi yang tidak disenangi oleh siswa. Hal tersebut mengakibatkan siswa asal-asalan dalam membaca biografi. Oleh sebab itu, dibutuhkan metode pengajaran yang bisa membangun motivasi serta fokus siswa, supaya siswa mampu membaca pemahaman biografi.

Supaya tujuan pembelajaran bisa tercapai, dalam penelitian ini digunakan metodeExtending Concépts Throught Language Activities (ECOLA).

Abidin, (2012, hlm. 81) menyebutkanbahwaMetode ECOLA merupakan salah satu metode dalam pembelajaran membacayang dikembangkan oleh Smith-Burkepada tahun 1982. Metode ini bisa meningkatkan keterampilan membaca. Metode ini merupakan penggabungan dari empat keterampilan berbahasa yaitu mendengarkan, berbicara, membaca, dan menulis.

Abidin (2012, hlm. 82) menyebutkan langkah-langkah menggunakan metode ECOLA, yaitu menentukan tujuan komunikatif, membaca dalam hati, menulis pemahaman, berdiskusi mengenai materi bacaan, dan menulis serta membandingkan hasil interpretasi.

Dari uraian diatas dapat disimpulkan bahwa yang dimaksud metode ECOLA merupakan metode yang menggunakan empat keterampilan berbahasa secara langsung dalam pelajaran membaca.

Tujuan dalam penelitian ini yaitu untuk mengetahui kemampuan awal dan ahir siswa dalam membaca pemahaman biografi, meningkatnya pemahaman siswa, dan adanya beda yang signifikan mengenai kemampuan membaca pemahaman biografi siswa kelas XI IPA 2 SMA Laboratorium Percontohan UPI Bandung tahun pelajaran 2013/2014 sebelum dan sesudah menggunakan metode ECOLA.

\section{MÉTODE}

Metode yang digunakan dalam penelitian ini yaitu metode kuasi ékspérimén. Metode kuasi ékspérimén memiliki tujuan untuk mengetahui bagaimana kemampuan awal siswa dalam membaca pemahaman biografi sebelum menggunakan metode ECOLA (prétés), dankemampuan akhir siswa dalam membaca pemahaman biografi sesudah menggunakan metode ECOLA (postés).

Desain yang digunakan dalam penelitian ini adalah One-group pretest and posttest design, yaitu eksperimen yang dilaksanakan dalam satu kelompok saja, tanpa membutuhkan kelompok pembanding (Arikunto, 2010, hlm. 212).

\section{$\mathrm{O}_{1} \mathrm{X} \mathrm{O}_{2}$}

\section{Keterangan:}

$\mathrm{O}_{1}$ : prétés

$\mathrm{O}_{2}$ : postés

$\mathrm{X}$ :treatment (modél pengajaran ECOLA)

Instrumen yang digunakan dalam penelitian ini yaitu instrumen tes dalam bentuk pilihan ganda. Tes ini dilakukan sebanyak dua kali yaitu tes awal (prétés) untuk mengukur kemampuan membaca pemahaman biografi siswa sebelum menggunakan metode ECOLA, dan tes akhir (postés)untuk mengukur kemampuan membaca pemahaman biografi siswa sesudah menggunakan metode ECOLA.

Sumber data dalam penelitian ini adalah siswa kelas XI IPA 2 SMA Laboratorium Percontohan UPI tahun pelajaran 2013/2014, dengan jumlah siswa sebanyak 28 orang. Data dalam 
penelitian ini adalah hasil pretes dan postes dalam bentuk pilihan ganda.

Dalam menganalisis data, terdapat beberapa langkah yang harus dilaksanakan, yaitu: 1) memeriksa dan memberi skor hasil pretes dan postes siswa; 2) uji sifat data, yang terbagi menjadi uji normalitas dan uji homogénitas; 3) uji gain; dan 4) uji hipotésis.

\section{HASIL DAN PEMBAHASAN}

Berdasarkan hasil penelitian dan analisis data, didapatkan bahwa kemampuan membaca pemahaman biografi siswa kelas XI IPA 2 SMA Laboratorium Percontohan UPI tahun pelajaran 2013/2014 sebelum menggunakan metode Exténding Concepts Throught Language Activities (ECOLA)tergolong kedalam kritéria belum mampu. Skor rata-rata dalam membaca pemahaman sebelum menggunakan metode ECOLA adalah 63,59. Berdasarkan tiga aspek pemahaman, didapatrata-rata nilaiyaitu, literal 13, interpretasi 5, dan elaborasi 1,4. Anderson dalam Kuswari (Awalia Evita, Skripsi, 2013, hlm. 22).Skor tersebut belum mencapaiKriteria Ketuntasan Minimal (KKM) Basa Sunda SMA Laboratorium UPI yaitu 75.

Setelah diberi treatment, dan dilaksanakan postes, kemampuan membaca pemahaman siswa kelas XI IPA 2 SMA Laboratorium UPI menjadi meningkat. Kamampuan membaca pemahaman biografi setelah menggunakan metode ECOLA tergolong kedalam kritéria mampu, dengan skor rata-rata 78,59. Berdasarkan tiga aspek pemahaman, rata-rata nilainya yaitu, literal 17, interpretasi 5,2, dan elaborasi 1,9. Skor tersebut di atas KKM yang sudah ditentukan yaitu 75 .

Setelah itu,dilaksanakan uji sifat data, yaitu uji normalitas dan uji homogénitas.

\section{Uji Normalitas}

Uji normalitas dilaksanakan untuk mengetahui normal tidaknya distribusi suatu data. Uji normalitas terbagi menjadi uji normalitas pretes dan uji normalitas postes (Subana, 2000, hlm.126).

Berdasarkan hasil uji normalitas data pretes, terlihat bahwaX ${ }^{2}$ itung < $\mathrm{X}^{2}$ tabel,-21< 11,3. Sehingga distribusi nilai pretes dalam taraf kepercayaan $99 \%$ adalah normal.

Berdasarkan hasil uji normalitas data postes, terlihatbahwaX2itung < $\mathrm{X}^{2}$ tabel, $-23.14<11.3$. sehingga distribusi nilai postés dalam taraf kepercayaan $99 \%$ adalah normal.

\section{Uji Homogénitas}

Uji homogénitas yaitu uji sifat data yang memiliki tujuan untuk mengetahui homogen tidaknya variasi data. Berdasarkan hasil hitung, dapat diketahui bahawa Fitung 1,07<Ftabél 4.10, artinya data pretes dan data postes termasuk varian yang homogeny (Sudjana, 2005, hlm. 250).

\section{Uji Gain}

Uji gain dilaksanakan untuk mengetahui apakah ada beda yang signifikan antara kemampuan membaca pemahaman siswa kelas XI IPA 2 SMA Laboratorium Percontohan UPI tahun pelajaran 2013/2014 sebelum dan sesudah menggunakan metode ECOLA. Untuk mengetahui hasil uji gain, bisa dilihat dalam tabel di bawah ini.

Tabél 1

Perbedaan Rata-rata Pretes dan Postes
\begin{tabular}{ccc} 
Pretes & Postes & D \\
\hline $\mathbf{6 3 , 5 9}$ & 78,59 & 15 \\
\hline
\end{tabular}

Berdasarkan tabel di atas, terlihat adanya perbadaan antara kemampuan membaca pemahaman biografi siswa sebelum dan sesudah menggunakan metode ECOLA. Hasil pretesdengan ratarata 63,59 meningkat ketika postes menjadi 78,59.Hal ini sesuai dengan teori 
yang dikembangkan oleh Smith-Burke (dalam Abidin, 2012, hlm.81) bahwa metode ECOLA bisa meningkatkan keterampilan membaca.

Meningkatnya kemampuan membaca pemahaman biografi siswa kelas XI IPA 2 SMA Laboratorium Percontohan UPI disebabkan oleh meningkatnya skor siswa pada setiap aspek yang dinilai. Hal tersebut bisa dilihat pada tabel di bawah.

Tabél 2

Rata-rata perbandingan setiap aspek PretesdanPostes

\begin{tabular}{cccccccc}
\hline \multicolumn{4}{c}{ Prétés } & \multicolumn{4}{c}{ Postés } \\
\hline $\mathbf{A}$ & $\mathbf{B}$ & $\mathbf{C}$ & $\boldsymbol{\Sigma}$ & $\mathbf{A}$ & $\mathbf{B}$ & $\mathbf{C}$ & $\boldsymbol{\Sigma}$ \\
\hline $\mathbf{1 3}$ & 5 & 1,4 & 19,08 & 17 & 5,2 & 1,9 & 23,58 \\
\hline
\end{tabular}
Keterangan
A : Literal
B : Interpretasi
C : Elaborasi
$\Sigma:$ Jumlah

Berdasarkan tabel di atas, adanya perbedaan pada setiap aspek yang dinilai antara pretes dan postes. Sebelum menggunakan ECOLA, rata-rata dari aspék literal 13, sesudah menggunakan metode ECOLA menjadi 17. Aspék interpretasi sebelumnya 5, sesudah menggunakan metode ECOLA menjadi 5,2. Aspék elaborasi sebelumnya 1,4, sesudah menggunakan metode ECOLA menjadi 1,9. Begitu juga dengan jumlah seluruh aspek terjadi peningkatan. Sebelum menggunakan metode ECOLA, rata-rata jumlahnya yaitu 19,08, sesudah menggunakan metode ECOLA menjadi 23,58 .

\section{Uji Hipotesis}

Uji hipotesis dilaksanakan sesudah menghitung uji normalitas, uji homogenitas, serta uji gain. Uji hipotesis memiliki tujuan untuk mengetahui hipotesis mana yang diterima dan hipotesis mana yang ditolak. Dikarenakan distribusi datanya normal,sehingga rumus yang digunakan yaitu rumus statistik parametris. Uji hipotesis bisa dilihat pada tabel di bawah.

Tabél 3

Hasil Hitung Uji Hipotésis

\begin{tabular}{ccccc}
\hline $\mathbf{N}$ & Db & Thitung & Ttabél & $\begin{array}{c}\text { tabél } \\
\mathbf{t ~ 0 , 0 5}\end{array}$ \\
\hline $\mathbf{2 6}$ & 25 & 11,03 & 2,48 & Signifikan \\
\hline
\end{tabular}

Berdasarkan hasil hitung pada tabel 3 , terbukti bahwath itung $>t_{\text {tabél }}$ atau 11,03 $>$ 2,48.Artinyahipotesis alternatif (Ha) diterima serta hipotesis nol (Ho) ditolak. Dengan begitu dalam taraf kepercayaan 99\%, ada béda yang signifikan antara tes awal dan tes akhir. Dapat disimpulkan bahwa, metode ECOLA cocok digunakan dalam meningkatkan kemampuan membaca pemahaman biografi siswa kelas XI IPA 2 SMA Laboratorium Percontohan UPI tahun pelajaran 2013/2014.

\section{SIMPULAN}

1. Kemampuan membaca pemahaman sebelum menggunakan metode ECOLA siswa belum mampu, dengan rata-rata pemahaman 63,59. Berdasarkan tiga aspek yang dinilai, aspek literal 13, interpretasi 5, dan elaborasi 1,4. Sedangkan setelah menggunakan metode ECOLA,siswa menjadi mampu membaca pemahaman biografi, dengan rata-rata pemahaman 78,59. Berdasarkan tiga aspek yang 
dinilai, aspék literal 17, interpretasi 5,2, dan elaborasi 1,9.

2. Kemampuan membaca pemahaman biografi siswa meningkat dari 63,59, menjadi 78,59. Dari yang tadinya belum mampu, menjadi mampu membaca pemahaman biografi.

3. Terdapat perbedaan yang signifikan antara kemampuan membaca pemahaman biografi siswa sebelum dan sesudah menggunakan metode ECOLA. Dalam taraf kepercayaan 99\%, berdasarkan hasil hitung, didapatkan bahwa, thitung 11,03 > ttabel 2,48, oleh karena itu, hipotésis kerja (Ha) diterima dan hipotésis nol (H0) ditolak, terdapat béda yang signifikan antara tés awal dan tés akhir. Metode ECOLA cocok digunakan dalam meningkatkan kemampuan membaca pemahaman biografi siswa kelas XI IPA 2 SMA Laboratorium Percontohan UPI tahun ajaran 2013/2014.

\section{PUSTAKA RUJUKAN}

Abidin, Y. (2012). Pembelajaran Membaca Berbasis Pendidikan Karakter. Bandung: Refika Aditama.

Arikunto, S. (2010a). Prosedur Penelitian. Jakarta: Rineka Cipta.
Awalia, E.M. (2013). Modél Pangajaran Word Square pikeun Ngaronjatkeun Kamampuh Maca Pamahaman. Skripsi JPBD UPI Bandung: tidak diterbitkan.

Haerudin, D. Spk. (2013b). Panganteur Kaparigelan Nyarita. Bandung: JPBD FPBS PI.

Rahayu, M. (2011). Eféktifitas Media Majalah Dingding (Mading) dina

Pangajaran Nulis Biografi. Skripsi JPBD UPI Bandung: tidak diterbitkan.

Somadayo, S. (2011). Strategi dan Teknik Pembelajaran Membaca. Yogyakarta: Graha Ilmu.

Subana. (2000). Statistik Pendidikan. Bandung: Pustaka Setia.

Sudjana. (2005). Metoda Statistika. Bandung: Tarsito

Tarigan, H.G. (2008). Membaca Sebagai suatu Keterampilan Berbahasa. Bandung: Angkasa.

\section{UCAPAN TERIMA KASIH}

Terima kasih kepada pengelola jurnal Lokabasa yang telah menerbitkan tulisan ini. Semoga tulisan ini ada manfaatnya bagi perkembangan ilmu pengetahuan. 